\title{
病院・薬局処方で粉砕される市販錠剤からのラジカルの生成
}

\author{
葛谷昌之, ${ }^{*}$ 近藤伸一, 石川敬章, 古田陽司,
} 荒巻秀樹，笹井泰志，山内行玄

\section{Radical Formation by Grinding of Commercial Tablets according to Hospital and Pharmacy Prescription}

\author{
Masayuki KuZuYa, ${ }^{*}$ Shin-ichi Kondo, Takaaki IshIKAwA, Youji Furuta, \\ Hideki ARAMAKI, Yasushi SASAI, and Yukinori YAMAUCHI \\ Laboratory of Pharmaceutical Physical Chemistry, Gifu Pharmaceutical University, \\ 5-6-1 Mitahora-Higashi, Gifu 502-8585, Japan
}

(Received December 1, 2004; Accepted January 25, 2005)

\begin{abstract}
We examined mechanoradical formation in the grinding process of commercial tablets using electron spin resonance (ESR). Mechanoradicals were detected in all tested samples (23 types of commercial tablets) when the ballmilling of tablets was conducted under anaerobic conditions and some were fairly stable even in air. Thus the grinding may cause changes in the physicochemical properties of ingredients included in commercial tablets. Because high quality is demanded in pharmaceuticals, these results suggest more caution should be taken in the grinding of commercial tablets in hospitals and pharmacies.
\end{abstract}

Key words_— mechanoradicals; mechanochemical reaction; commercial tablets; electron spin resonance

緒言

疾病による嚥下障害や嚥下能力のない小児・高齢 者に対し，あるいは市販製剤では投与薬用量の調節 が困難などの理由により，病院薬局や調剂薬局にお いて，止むを得ず（めのう）乳鉢や錠剂粉砕機を用 いた錠剂の粉砕やカプセル剂の開封が行われてい る。 その頻度は，外来処方箋の約 $6 \%$, 院内取扱品 目（内用錠剤・カプセル剂）の約 $19 \%$ にも当たる と報告されている. 1) その際, 本来の製剤特性が失 われることがあるために，製剤の物理学的安定性に 対する影響，体内動態や薬効・副作用に対する影 響, 苦味や刺激感などの感覚器への影響, 調剤上の ロスや配合変化など様々な問題点を考慮する必要が ある. ${ }^{2)}$ 事実，病院・薬局処方に基づく医薬品錠剂 の粉砕やカプセル剂の開封の可否に関する調査研究 を含めて，散剤や錠剤の粉砕の際に生じる薬剤の損 失) や粉砕試料中の粉体自身の集合体物性変化 ${ }^{4,5}$ な どに関する報告例は数多くある.

岐阜薬科大学薬品物理化学教室

e-mail: kuzuya @gifu-pu.ac.jp
一方，固体試料に粉砕・圧縮などの機械的エネル ギーを加える，いわゆる “メカノリシス” 操作にお いては，集合体物性変化のみならず，分子物性変化 も惹起することがある．特に，多くの高分子のメカ ノリシスでは，高分子主鎖が破断される結果，メカ ノラジカル生成とその逐次反応を含む“メカノケミ カル反応”が進行し，処理条件に依存した一定の分 子量（限界分子量）に向かって分子量が低下してい くことが知られている. 合成高分子のメカノラジカ ル生成に関する研究は古くから数多く行われている ものの，それらは，低温（77 K）で行われているも のがほとんどであり, 通常の粉砕操作が行われる室 温におけるメカノラジカル生成とその動力学に関す る詳細な研究報告例は見当たらなかった。

われわれは，室温メカノリシスに関する研究よ り，セルロースやアミロース（スターチ）などの多 糖類を含む各種高分子に生成するメカノラジカルの 構造と反応特性について明らかにするとともに, ${ }^{6,7)}$ その詳細な動力学的知見に基づいて，メ力ノケミカ ル固相重合を利用する新規高分子プロドラッグの構 築に関する一連の研究についても報告してきてい 
る. ${ }^{8)}$ また，われわれは，金属製（ステンレス製な

ぞ）の粉砕容器を用いる低分子量化合物の粉砕にお いても，金属表面からの固相一電子移動反応 （SSET 反応）が進行する事実を実験的に初めて実 証した. ${ }^{9)}$ すなわち，モデル化合物として，酸化還 元電位が低い（還元され易い）固体メチルビオロー ゲン（MV）とその誘導体である数種のビピリジニ ウムダイカチオン化合物を選択し，それらを室温， 無酸素条件下，ステンレス製容器を用いて振動ボー ルミル処理すると，その一電子還元体であるモノカ チオンラジカルが室温における ESR スペクトル測 定によって観測される，さらに，センナやケツメイ シなどの生薬成分の 1 つであるヒドロキシアントラ キノン（HAQ）誘導体 ${ }^{10}$ や，酸化還元電位が低い ビタミン類の 1 つであるリボフラビン (FR) ${ }^{11}$ にお いても，同様に SSET 反応が容易に進行することを 明らかにしている。

このような知見から，医薬品錠剂の粉砕に伴う真 の問題は，粉砕時に本来の製剂特性が失われるだけ でなく，メカノラジカル生成を含む錠剤成分物質 （主薬と医薬品添加物）のメカノケミカル反応によ る分子物性変化の可能性があることである。しかし ながら，医薬品錠剂を粉砕する過程で，かかる可能 性が検討された研究報告は見当たらない.

われわれは，錠剂粉砕時の分子物性変化に関する 知見を得るために，実際に病院・薬局処方において 粉砕される医薬品錠剂12)やその主薬と医薬品添加物 のメカノラジカル生成について，ESR スペクトル 測定によって検討した。

\section{試料と実験方法}

1. 試料 以下に記した 23 種の医薬品錠剤に ついて，市販品をそのまま粉砕に使用した。

アルダクトン ${ }^{\circledR} \mathrm{A}$ 錠（スピロノラクトン $25 \mathrm{mg}$, 大日本製薬），アレビアチン錠（フェニトイン 100 $\mathrm{mg}$ ，大日本製薬），アモバン錠（ゾピクロン 7.5 $\mathrm{mg}$, 中外製薬), アーテン錠（塩酸トリヘキシフ エニジル $2 \mathrm{mg}$, 武田薬品工業), アーチスト®錠 (カルペジロール $10 \mathrm{mg}$, 第一製薬), ベンザリン® 錠 (ニトラゼパム $5 \mathrm{mg}$, 塩野義製薬), セルシン 錠（ジアゼパム $2 \mathrm{mg}$, 武田薬品工業), シベノー ル『錠（コハク酸ジベンゾリン $50 \mathrm{mg}$, 藤沢薬品工 業)，ガスター錠（ファモチジン $10 \mathrm{mg}$ ，山之内製
薬），デパケン ${ }^{\circledR} \mathrm{R}$ 錠（バルプロ酸ナトリウム 200 $\mathrm{mg}$ ，協和発酵），ジゴシン錠（ジゴキシン 0.25 $\mathrm{mg}$, 中外製薬), フロモックス錠 $100 \mathrm{mg}$ (塩酸セ フカペン $100 \mathrm{mg}$, 塩野義製薬），ラシックス錠 (フロセミド $20 \mathrm{mg}$, ヘキスト)，メチコバール錠 (メコバラミン $500 \mu \mathrm{g}$, エーザイ)，ムコダイン®錠 (カルボシステイン $250 \mathrm{mg}$, 杏林製薬)，パナルジ ン錠（塩酸チクロピジン $100 \mathrm{mg}$ ，第一製薬），プ リンペラン®錠（メトクロプラミド $5 \mathrm{mg}$, 藤沢薬品 工業)，プロパジール錠（プロピルチオウラシル $50 \mathrm{mg}$ ，中外製薬），プルゼニド錠（センノシド 12 $\mathrm{mg}$, ノバルティス), リボトリール錠（クロナゼ パム $0.5 \mathrm{mg}$, ロシュ), リスモダン ${ }^{\circledR} \mathrm{R}$ 錠（ジソピ ラニド $150 \mathrm{mg}$ ，中外製薬），セレネース『錠（ハロ ペリドール $0.75 \mathrm{mg}$ ，大日本製薬），タガメット錠 (シメチジン $200 \mathrm{mg}$, ビーチャム).

上記の 23 種類の市販錠剤の中, 下線を記した 17 種の主薬は，それぞれの錠剤の製造メーカーから提 供を受けて，恒量となるまで室温にて減圧乾燥した のち，粉砕に使用した.

結晶セルロース（アビセル PH-102，旭化成(侏)， コーンスターチ (キシダ化学侏), 無水乳糖（ナカ ライテスク秼）は，60-100メッシュに篩下し，恒

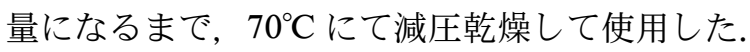

2. 自動乳鉢を用いる医薬品錠剂の粉砕市販 錠剂を室温大気中において自動めのう製乳鉢（パル バリゼット 2, フリッチュ・ジャパン株，操作条 件 : $610 \mathrm{~J} / \mathrm{kg} / \mathrm{s}$ ) を用いて，錠剂からの粉末が 200 メッシュ篩下するまで粉砕した。粉砕した試料のう ち約 $100 \mathrm{mg}$ を ESR チューブへ採取して，ESR ス ペクトルを測定した.

3. 金属製ボールミルを用いた粉砕 市販錠剂 のボールミル粉砕は, 前処理として, 室温無酸素条

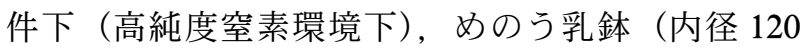
$\mathrm{mm} \phi$, 深さ $55 \mathrm{~mm}$ ，アズワン侏）を用いて小片と し，得られた錠剤片（100 mg）を金属製二蓋性ブ レンダー容器（内径 $10 \mathrm{~mm}$, 長さ $22 \mathrm{~mm}$ ）に金属製 ボール（直径 $6.0 \mathrm{~mm}, 890 \mathrm{mg}$ ）とともに入れ，室 温無酸素条件下，振動ボールミル粉砕機 $\left(\right.$ Retsch $^{\circledR}$ MM2000,レッチェ(侏) により，自動乳鉢を用いた 粉砕条件と等しい $610 \mathrm{~J} / \mathrm{kg} / \mathrm{s}$ （振動周波数 $33 \mathrm{~Hz}$ ) にて所定時間処理した.

主薬並びに添加物のボールミル粉砕は, 所定量の 
試料を金属製二蓋性ブレンダー容器（内径 7.8 $\mathrm{mm}$, 長さ $24 \mathrm{~mm}$ ）に金属製ボール（直径 $6.0 \mathrm{~mm}$, $890 \mathrm{mg}$ ）とともに入れ，室温無酸素条件下，振動 ボールミル粉砕機（島津製作所株）により，5000 J/ $\mathrm{kg} / \mathrm{s}$ （振動周波数 $60 \mathrm{~Hz}$ ）にて所定時間処理した.

その後，粉砕試料を無酸素条件下にて ESR チ ユーブに採取し，密封したのち，ESR スペクトル を測定をした.

\section{ESR スペクトル測定ＥSRスペクトルは,} JES-RE1X 型 ESR スペクトロメーター（日本電子 侏）を用いて，磁場変調 $100 \mathrm{kHz}$ ，共鳴周波数 9.435 $\pm 0.005 \mathrm{GHz}$ ，磁場変調幅 $0.1 \mathrm{mT}$, 及びマイクロ波 出力としてスペクトルが飽和しない最大出力 0.04 $\mathrm{mW}$ にて測定した，ESR スペクトル強度は，スペ クトルの二回積分より求めた．ラジカル濃度は，既 知濃度の 1,1-diphenyl-2-picrylhydrazyl（DPPH）を 含有したポリメタクリル酸メチルの粉末サンプルか ら得られたスペクトル $(\mathrm{g}=2.0036)$ 強度一ラジカ ル量の検量線を用いて算出した。

5. 放置実験 乾燥空気中での放置実験は，無 酸素条件下においてボールミル粉砕した試料をシリ カゲル乾燥管を付けた ESR チューブに移し，その 後, 室温空気中にて放置し, 経時的に ESR スペク トルを測定することにより実施した.

\section{結 果 と考察}

1. 市販錠剂の粉砕によって生成するラジカル 23 種の市販錠剂を実際に粉砕操作が行われる室温
空気中において，自動めのう乳鉢を用いて粉砕し た。その粉末試料の ESR スペクトル測定の結果, センノシドを含有した錠剤(以下，プルゼニド錠), 塩酸セフカペンを含有した錠剤（以下，フロモック 又錠），及びバルプロ酸ナトリウムを含有した錠剤 (以下，デパケン $\mathrm{R}$ 錠)の 3 種の粉砕試料について,

Fig. 1 に示す ESR スペクトルが観測された。これ らのスペクトルは，いずれも複数のラジカル種を含 み，正確な $\mathrm{g}$ 值の算出は困難であったが，炭素中心 ラジカルに由来するピークであることが示唆され た.このように，空気中においても数種の医薬品か らメカノラジカルの生成が ESR によって確認され た.

そこで，市販錠剂の粉砕時におけるメカノラジカ ル生成の有無をさらに正確に検討するため, 室温無 酸素条件下において，めのう乳鉢を用い錠剤粗片と したものをボールミルにより 15 分間粉砕した。そ の結果，定性的にはすべての錠剤の粉砕試料からメ カノラジカルの生成が確認された。そのうち，本 ESR スペクトル測定条件下，ピークとして明確に 認識できるラジカル生成量が $1 \times 10^{17}$ spin numbers/ $\mathrm{g}$ 以上の粉砕試料の ESR スペクトルを Fig. 2 に示 した，その外形は，様々であり，錠剂中の成分に起 因するメカノラジカルのスペクトルが，重なり合つ たものであることは明白である。これは，一般に錠 剤の調製には，高分子添加物を含め種々の医薬品添 加物が加えられているためである。したがって，こ れらのスペクトルの正確な解析は困難であるが，病

\section{Pursennid}

Flomox

Depakene R
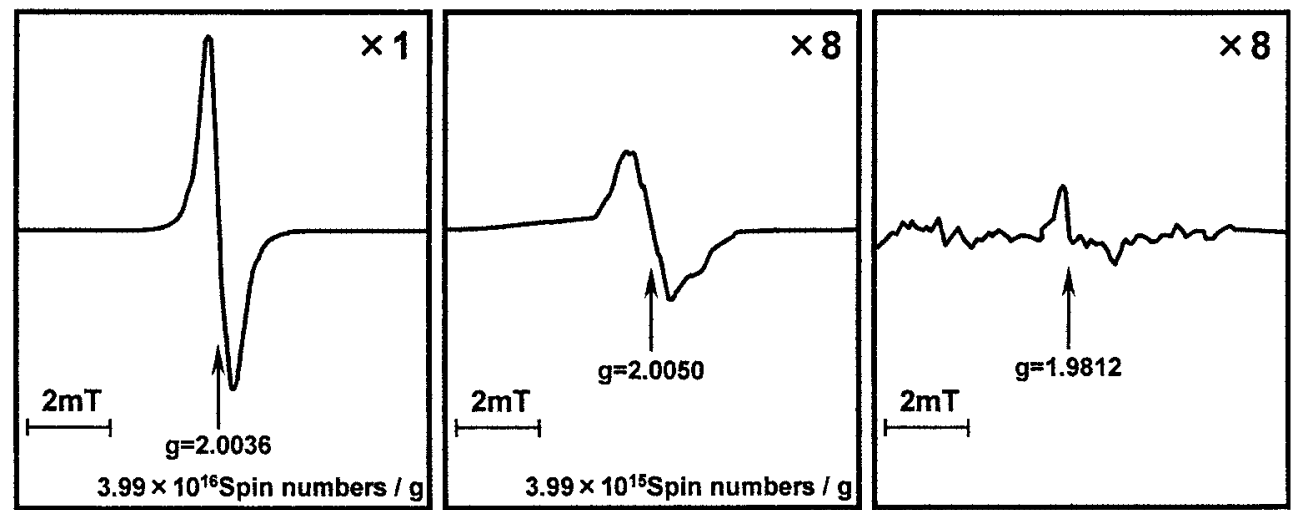

Fig. 1. Observed ESR Spectra of Pursennid, Flomox and Depakene R Ground by Agate-made Mortar-machine in Air at Room Temperature

Mechanical condition: $610 \mathrm{~J} / \mathrm{kg} / \mathrm{s}, 5 \mathrm{~min}$ 


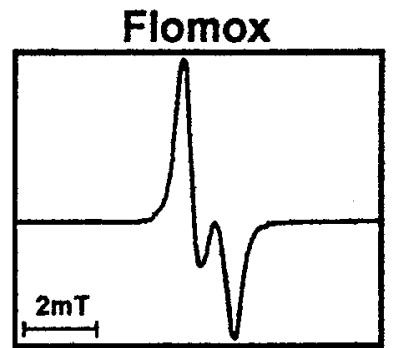

Methycobal

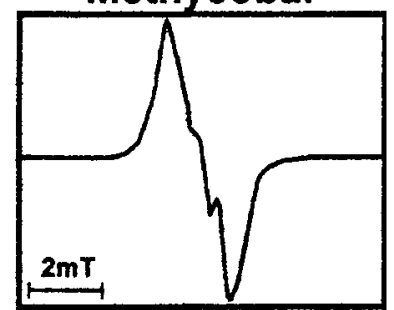

Gaster10

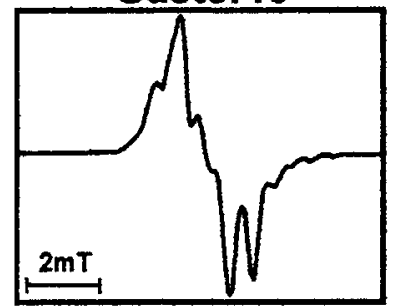

Pursennid

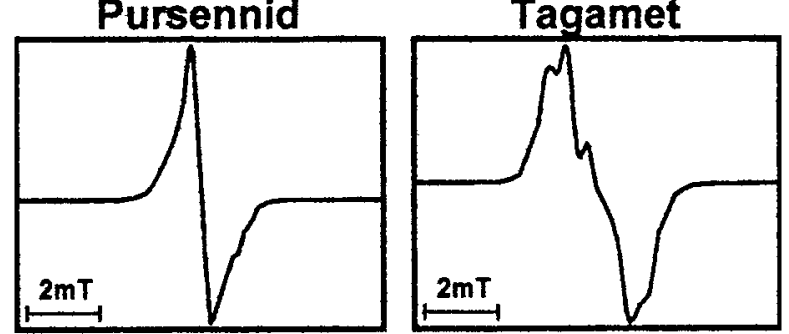

Panaldine

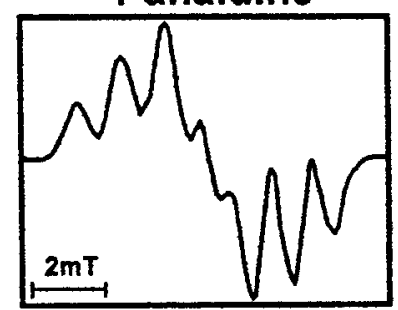

Fig. 2. Observed ESR Spectra of Vibratory-milled Commercial Tablets under Anaerobic Conditions at Room Temperature

Mechanical condition: $610 \mathrm{~J} / \mathrm{kg} / \mathrm{s}, 15 \mathrm{~min}$.

院や薬局処方に基づいて，錠剤の粉砕が行われる 時，種々のラジカルが確実に生成していると言える.

2. 生成ラジカルと酸素との反応性実際に市 販錠剂が使用されるのは，当然，大気中であること から，生成ラジカルと空気中酸素との反応性につい て詳細に検討した。

Figure 3 は, 室温無酸素条件下, 市販錠剂をボー ルミル粉砕し，観測されたラジカルが $1 \times 10^{17} \mathrm{spin}$ numbers/g 以上の試料を空気に曝したときのラジカ ル量の経時変化を示したものである．プルゼニド錠 の粉砕試料中に存在するメカノラジカルは, 空気中 でも長時間安定に存在したのに対し，その他の錠剤 の粉砕試料中に存在するメカノラジカルは，短時間

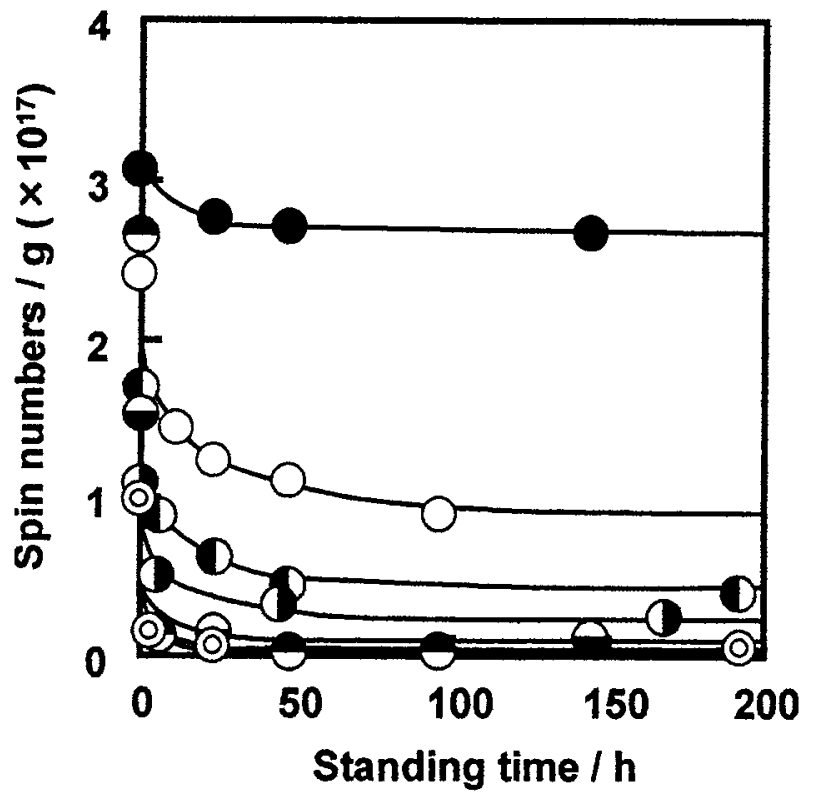

Fig. 3. Progressive Changes in Radical Concentration of Vibratory-milled Commercial Tablet on Standing in Air at Room Temperature

Mechanical condition: $610 \mathrm{~J} / \mathrm{kg} / \mathrm{s}, 15 \mathrm{~min}$. $\bigcirc$ : Pursennid, $\odot$ : Panaldine, $\bigcirc$ : Methycobal, $\bigcirc$ : Flomox, $\odot$ : Tagamet, $($ : Gaster 10, ○: Primperan.

で失活する傾向にあった。これは，プルゼニド錠以 外の粉砕試料中には，空気中において非常に不安定 な種々のラジカル種が存在したことを示唆してい る.一方，プルゼニド錠の粉砕試料中に存在するメ カノラジカルの安定化の理由は, 粉砕試料中に存在 する複数のメカノラジカル種のうち, 空気中におい ても自ら安定に存在できるラジカル種が存在するた め，または，生成したラジカルが錠剤中の他の成分 によって安定化されているためと考えられる。した がって，空気中での粉砕時にラジカルが観測されな くても，ラジカルが生成しており，わずかながらで あるものの分子物性変化（化学構造変化）を来して いることは確実である.

3. 主薬のメカノケミカル反応により生成するラ ジカル 医薬品錠剤の粉砕により生成するラジカ ルは，主に高分子医薬品添加物に由来するものと考 えられるが，入手可能であった 17 種類の主薬につ いても，ボールミル粉砕によるメカノラジカル生成 の有無について ESR スペクトル測定によって検討 した.

その結果, 17 種類の主薬のうち, 緩下剤である センノシドと強心薬であるジゴキシンから, Fig. 4 に示す ESR スペクトルが観測された。それらは, 
Sennoside

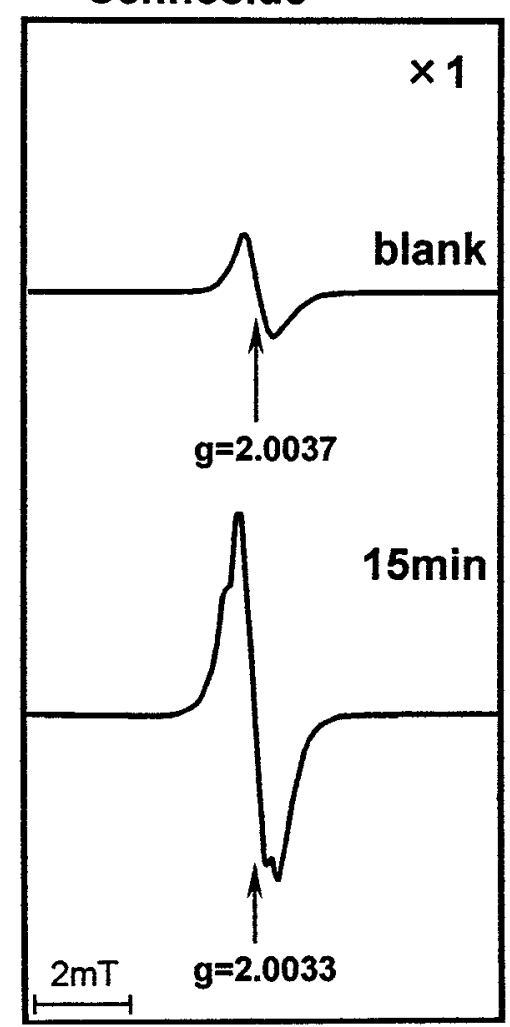

Digoxin

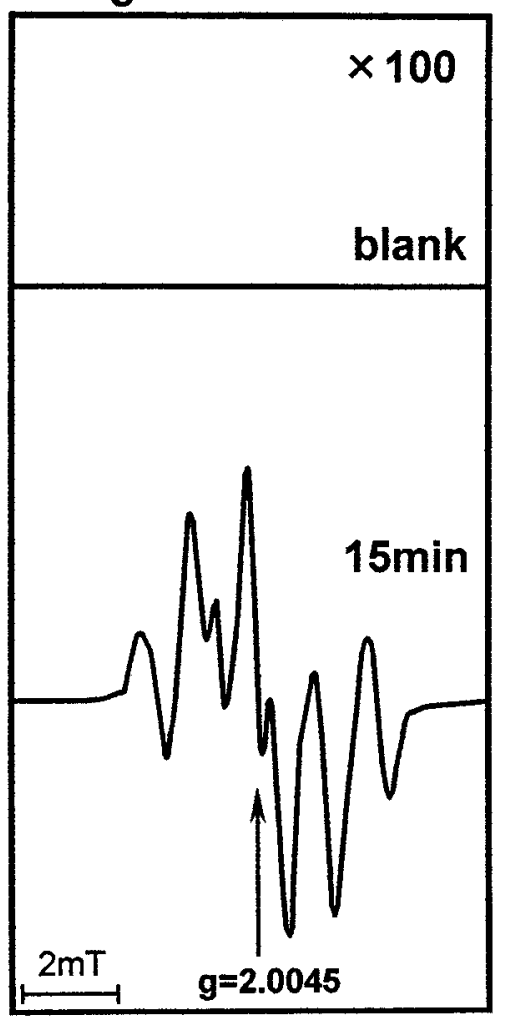

Fig. 4. Observed ESR Spectra of Vibratory-milled Sennoside and Digoxin under Anaerobic Conditions at Room Temperature Mechanical condition: $5000 \mathrm{~J} / \mathrm{kg} / \mathrm{s}, 15 \mathrm{~min}$.

外形及び $\mathrm{g}$ 值の概算值がともに 2.004 付近であるこ とから, 両者ともに複数の炭素中心ラジカルが生成 していることが示唆された.

ついで, これらの生成ラジカルと酸素との反応性 について検討した. Figure 5 は, 生成ラジカルを空 気に曝したときの ESR スペクトル変化を示したも のである.

センノシドラジカルは，そのスペクトル外形に変 化を伴わず，長期間安定に存在した。 センノシドは センナ配糖体のカルシウム塩であり，HAQ と類似 の分子構造であることから，この結果は，以前報告 したように, HAQ 誘導体と同様なメタルコンプレ ックス形成によるものと考えられる. ${ }^{10)}$

一方，ジゴキシンラジカルは，空気との接触によ り短時間で急速に失活した。これは，粉末 X 線回 折スペクトル測定の結果, 結晶構造の未粉砕試料が 振動処理により完全に非晶質化しており，その結 果，内部まで酸素の拡散が容易になったことも一因 と考えられる.したがって，ジゴキシン錠を空気中 で粉砕したときに検出感度範囲内においてラジカル
が観測されなかったのは，生成メカノラジカルが空 気中において不安定であるためと考えられる.

4. 賦形剂添加によるラジカル量の変化 すべ ての医薬品は製剤として使用されるとき，賦形剤な ご何らかの医薬品添加物を含んでおり，この添加物 の選択と使用方法が安定性や有効性に大きな影響を 与えている. 医薬品添加物の中でも大きな割合を示 しているのが，セルロース（アビセル）とその誘導 体，並びにアミロース（コーンスターチ）に代表さ れる多糖類である. ${ }^{13,14)}$

われわれは，これまでに，所定条件下の粉砕によ り，低分子量体である二糖類の乳糖は，検出範囲内 においてラジカルは観測されないが，アビセルを始 め多糖類では，高分子主鎖の破断によりラジカルが 生成し, 高分子マトリックスによって安定化される ために，室温の ESR スペクトル測定においても生 成ラジカルが観測されることを明らかにしてい る. 6,7$)$

ところで，賦形剂は単独で用いられることは少な く，アビセルと乳糖，若しくはコーンスターチと乳 


\section{Sennoside}

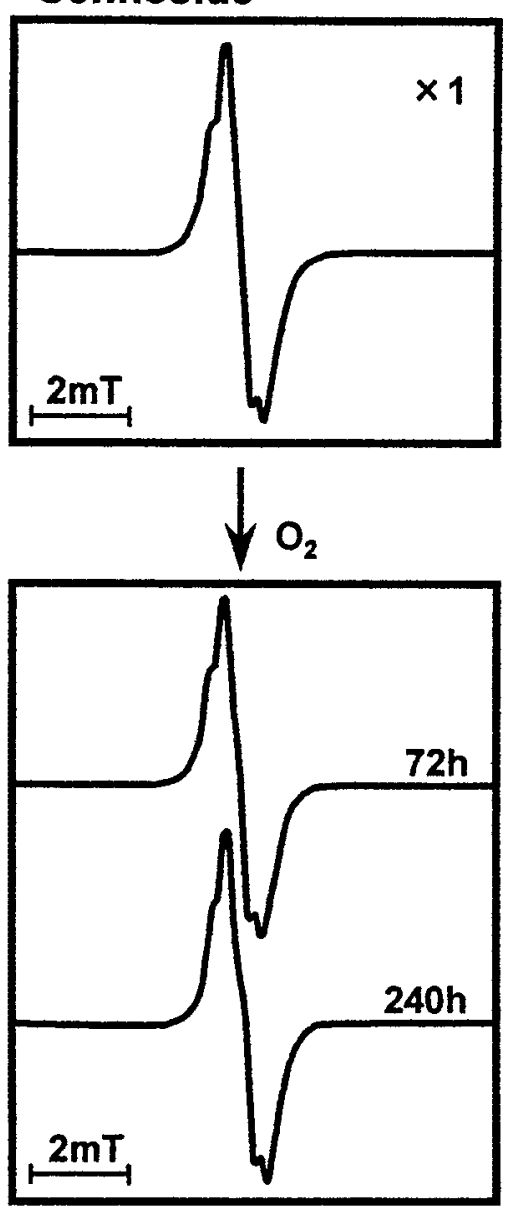

Digoxin
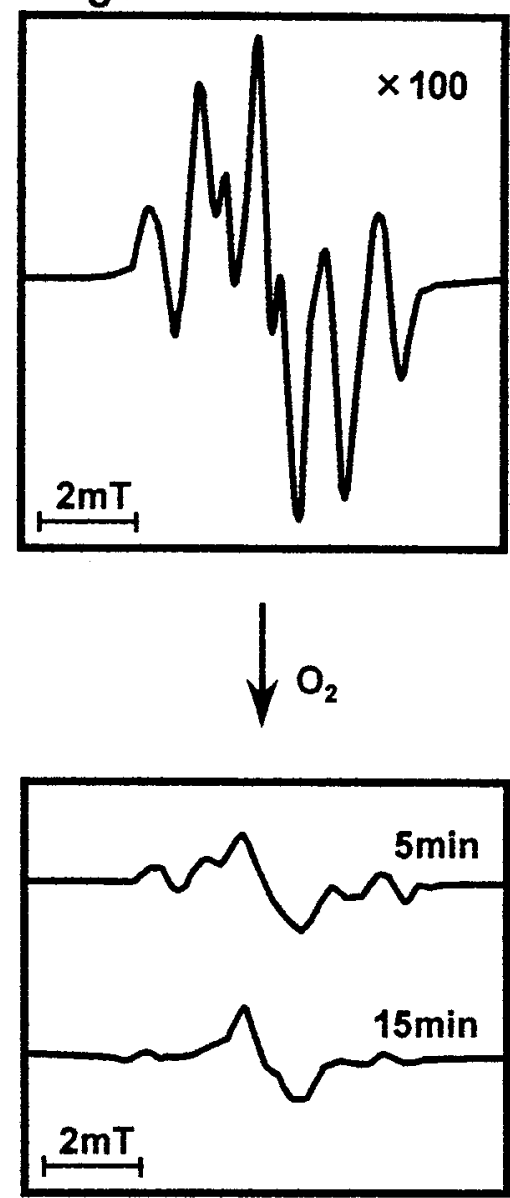

Fig. 5. Progressive Changes in ESR Spectra of Vibratory-milled Sennoside and Digoxin on Standing in Air Mechanical condition: $5000 \mathrm{~J} / \mathrm{kg} / \mathrm{s}, 15 \mathrm{~min}$.

糖などの組み合わせで用いられるのが一般的であ る.15) そこで，アビセルやコーンスターチのメカノ ラジカル生成に対する乳糖の影響を調べるために, 両者の混合物のボールミル粉砕を実施した.

Figure 6 は，アビセルあるいはコーンスターチに 対する乳糖の比率を横軸にとり, ラジカル生成量を プロットしたものである。 なお，ラジカル生成量 は，アビセル又はコーンスターチの単位グラム当た りに換算した。乳糖の含有率の増加に伴い, ラジカ ル生成量は増加した。すなわち，アビセル及びコー ンスターチは，比較的硬度の高い結晶性乳糖 ${ }^{16)}$ の粉 砕補助的な効果を受け，高分子主鎖の破断が促進さ れるものと考えられる．なお，アビセルのラジカル 量がスターチに比べて著しく増加傾向を示している が，これは，アビセルの分子量がスターチに比べて 大きい（約 3 倍）ためである. ${ }^{6}$
結

論

医薬品錠剤（23 種類）のメカノケミカル反応に より，本実験条件においてすべての粉砕試料よりメ カノラジカル生成が定性的に確認され，中には空気 中において安定に存在したものもあった。また，医 薬品錠剤の主薬（17 種類）にメカノケミカル反応 を実施した結果, 本実験条件においてジゴキシンと センノシドよりメカノラジカル生成が確認され， ジ ゴキシン由来のラジカルは空気中において短時間で 失活したのに対し，センノシド由来のラジカルは長 時間に亘り安定に存在し，それぞれ異なる反応性を 示した.

代表的な賦形剂であるアビセル及びコーンスター チに対する乳糖の混合比を変えてメカノケミカル反 応を実施した結果, 乳糖の含有率の増加に伴い, ラ ジカル生成量が増加し, 特に, アビセルは著しく増 


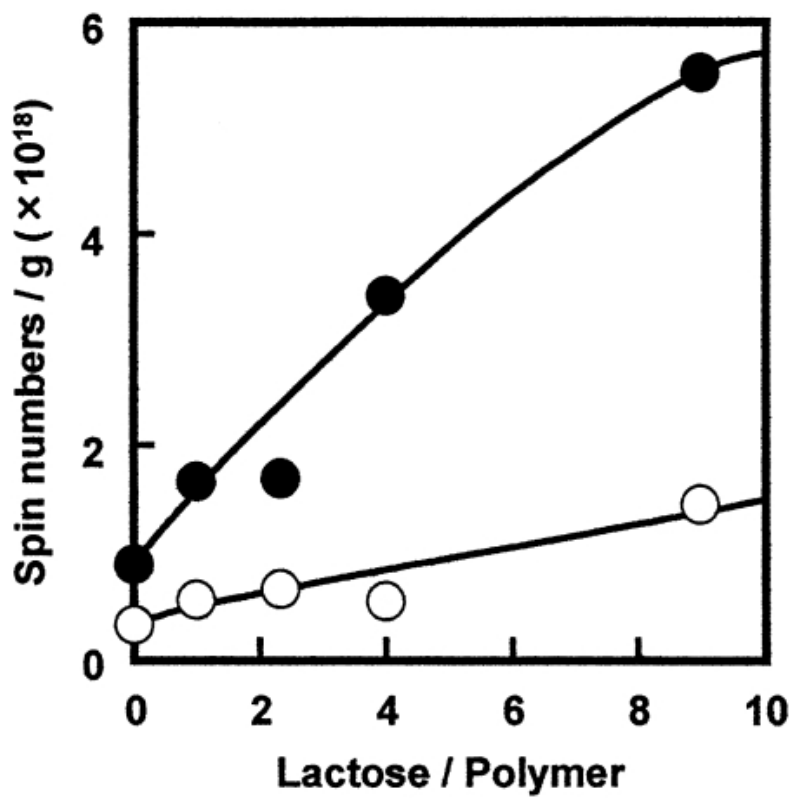

Fig. 6. Progressive Changes in Radical Concentration of Vibratory-milled Mixture Composed of Lactose and Avicel $(\bigcirc)$, or that of Lactose and Starch (O) with Differing the Ratio

Mechanical condition: $5000 \mathrm{~J} / \mathrm{kg} / \mathrm{s}, 30 \mathrm{~min}$, under anaerobic condition.

加したことから，アビセルとコーンスターチのいず れも乳糖の粉砕補助的な効果を受け，高分子主鎖の 破断が促進されていることが明らかとなった。

生成ラジカルと酸素との反応性について考察する に，一般に高分子ラジカルや有機ラジカルを空気に 曝すと，ESR スペクトル外形に変化を伴いなが ら，ラジカルは空気中の酸素と反応しパーオキシラ ジカルになり失活（消失）する，また，低分子であ る MV のモノカチオンラジカルの空気中における 失活は，酸素への 1 電子移動による反応であること が知られている．本研究に用いた粉砕試料中に存在 したラジカルの失活機構も同様に，上述の失活機構 のいずれかを経由していると考えられる.

ところで，SSET 反応が進行するには，粉砕され る物質が電子を授受し易い，すなわち，還元電位が 低くなければならない。本研究で使用した主薬のう ち，ジゴキシンは $-1.6 \mathrm{~V}$ ，塩酸セフカペンの母体 骨格であるセフェム系誘導体は－1-2 V であるこ とが報告されている。 ${ }^{17)}$ さらに，FRについては， その酸化還元電位が $\mathrm{pH} 7$ で $-0.292 \pm 0.005 \mathrm{~V}$ と低 <，FR は非常に還元され易い物質であり，われわ れは，実際に FR の SSET 反応の進行を確認してい る. ${ }^{11)}$ 上述のように，物質固有の酸化還元電位とい
う観点から考察するに，ジゴキシンや塩酸セフカペ ンを含めて SSET 反応が進行しているものは存在す るが，生成したラジカルの室温における安定性の違 いにより，本実験条件において観測可能であったも のと不可能であったものが存在したと考えられる.

また，SSET 反応は固相反応であるため，SSET 反 応に起因するラジカル生成には, 物質の結晶構造や 粉体の粒子径などが関与することも考えられる。

以上，本研究により得られた結果は，病院・薬局 処方における固体医薬品類の粉末化の過程において 一部分子物性変化が主薬あるいは添加物に生起して いることを示しており，厳重な分子物性を含む品質 が要求される医薬品においては, 錠剤の粉砕に伴う 様々な影響を改めて精査する必要性があることを示 唆している.

謝辞本研究を行うにあたり，医薬品原末の提 供を受けた塩野義製薬侏，ノバルティスファーマ 侏，中外製薬侏，エーザイ株の各社に謝意を表しま す.

\section{REFERENCES}

1) Tamura T., Sasahara H., Byouin Yakugaku, 15, 270-277 (1989).

2) Ogata A., Yamada Y., Iga T., Yakkyoku, 51, 1342-1349 (2000).

3) Suzuki M., Miyamoto S., Kohda Y., Nihon Byouin Yakuzaishikai Zasshi, 36, 347-351 (2000).

4) Tanoue N., Kaneko M., Tsuruta S., Matsushita R., Iwaoku R., Nakano M., Byouin Yakugaku, 21, 37-42 (1995).

5) Asaka K., Morioka H., Mukai J., Tsuji K., Ishizaka T., Yamashita J., Goto N., Koshiba T., Iyaku J., 26, 2211-2214 (1990) .

6) Kuzuya M., Yamauchi Y., Kondo S., J. Phys. Chem. B, 103, 8051-8059 (1999).

7) Sasai Y., Yamauchi Y., Kondo S., Kuzuya M., Chem. Pharm. Bull., 52, 339-344 (2004).

8) Kondo S., Kuzuya M., "Current Trends in Polymer Science," Vol. 3, 1998, pp. 1-23.

9) Kuzuya M., Kondo S., Murase K., J. Phys. Chem., 97, 7800-7802 (1993).

10) Kuzuya M., Kondo S., Yakugaku Zasshi, 111, 665-671 (1991).

11) Kondo S., Furuta Y., Okita S., Sasai Y., 
Aramaki H., Kuzuya M., Yakugaku Zasshi, 124, 141-148 (2004).

12) "Yakuzaishi no tameno Jouyou Iyakuhinsyuu," ed. by Tuji A., Hirokawa Syoten, 2002.

13) Kato K., "Keikouseizai no Syohou Sekkei," ed. by Hashida M., Yakugyou Jihousya, 1998.

14) “Iyakuhin Tenkabutsu Handbook," ed. by Nagai T. (general editor), Yakuji Nippousya, 2001 .
15) Takahashi Y., Ishihara T., Kashiwabara T., “Keikoutoyo Seizai no Syohou Sekkei,", ed. by Hashida M., Yakugyou Jihosya, 1998.

16) Williams III R. O., Sriwongjanya M., Barron M. K., Drug Dev. Ind. Pharm., 23, 695-704 (1997).

17) Ochiai M., Aki O., Morimoto A., Okada T., Shinozaki K., Asahi Y., J. Chem. Soc., Perkin Trans 1, 258-262 (1974). 